\title{
25 Research Soure \\ Adaptations of market garden producers to climate change in southern Mali
}

Tiémoko SOUMAORO ( $\nabla$ soumaoro.tiemoko@ugb.edu.sn )

Gaston Berger University: Universite Gaston Berger https://orcid.org/0000-0003-0182-2914

\section{Research Article}

Keywords: adaptation, climate change, multinomial logit, southern Mali, market gardeners

Posted Date: March 1st, 2021

DOI: https://doi.org/10.21203/rs.3.rs-176033/v1

License: (c) (i) This work is licensed under a Creative Commons Attribution 4.0 International License. Read Full License 


\title{
Adaptations of market garden producers to climate change in southern Mali
}

\section{Tiémoko SOUMAORO}

$\mathrm{PhD}$ student at the UFR of Economics and Management, Gaston Berger University (UGB) of Saint-Louis, Senegal.

\begin{abstract}
This article aims to identify the factors that influence the choice of adaptation measures by market garden producers in the extreme south of Mali in the face of climate change. The study used a multinomial logit regression model based on data collected from producers. Interviews with 194 producers were conducted in 3 circles in the southern region: Sikasso, Koutiala and Bougouni. The results of the multinomial logit model indicate that the mode of access to land, access to information on climate change, agricultural extension, agricultural experience and access to credit are the main endogenous strategies developed by producers to counteract the impacts of climate change. Finally, in order to consolidate these different strategies developed by producers, campaigns to raise awareness among producers on the importance of adapting to climate change should be encouraged.
\end{abstract}

Keywords: adaptation, climate change, multinomial logit, southern Mali, market gardeners.

\section{INTRODUCTION}

The impacts of climate change on ecosystems are unequivocal. In many respects, agriculture is one of the most affected strategic sectors. The reason for this is the natural relationship between harvesting and climatic conditions. Moreover, the relationship between climate change and agriculture is two-way: agriculture contributes to climate change in many ways, and climate change generally has negative impacts on agriculture (IPCC, 2013). According to Seguin (2010), a warming of $2^{\circ}-3^{\circ} \mathrm{C}$ will have potential effects on crop production. These effects 
will vary greatly depending on the regions and plant cover. Above this threshold, low-latitude regions will experience excessive temperatures and increased frequency of droughts. Bates and al (2008), Hartmann et al (2013) concur in stating that, in addition to temperature increase, climate change is associated with changes in the elements of the hydrological cycle on a large scale, such as an increase in atmospheric water vapor leading to changes in rainfall patterns, changes in the intensity of precipitation and extreme events, reduced snow cover and significant ice melt, and changes in freshwater content and soil runoff.

In West Africa, hydro meteorological disasters, particularly droughts and floods, are the most common forms of climate manifestation. The period 1930 to 1960 was considered wet, while the decade 1970-1980 was marked by droughts and the resumption of rainfall was observed in the years 1990 to 2000 illustrate and show how vulnerable the populations in the Sahelian zone are to climate variability (ECOWAS-SSA/OECD, 2008).

Mali is considered to be one of the most vulnerable countries in the world to climate change due to its geographical location (semi-arid tropical), but also due to its economic dependence on agriculture and the recurrence of natural risks (droughts and floods). Thus, droughts and floods account for $80 \%$ of the loss of life and $70 \%$ of the economic losses related to natural hazards in sub-Saharan Africa (Bhavnani et al. 2008). Between 1951-1970, there was a $20 \%$ drop in comparison with the reference period 1971-2000 leading to a displacement of isohyets by $200 \mathrm{~km}$ towards the South (MEDD, 2018). According to the same source, the $1200 \mathrm{~mm}$ isohyets no longer exist on the map of Mali. This shows how irregular the rainfall regime in Mali is.

Faced with these challenges, in order to increase food and nutrition security, farming communities in Mali's regions have developed adaptation strategies that improve the productivity, 
efficiency, profitability and equity of their agricultural production and marketing systems (UNDP, 2014).

In addition, agriculture provides employment for more than $70 \%$ of the rural population and is the main source of income (World Bank, 2014). With the galloping urbanisation of Malian cities, there is a strong increase in the demand for market garden products, resulting from the modification of consumer habits. In this case, market gardening appears to be a sector in the making. Moreover, most market gardening systems are initially not very capital intensive.

Moreover, market gardening is an income generating activity for the farmers. Not only does it improve their socio-economical living conditions, but it also helps them to cope with the recurrent problem of food insecurity.

However, current and future climatic disturbances risk compromising the development of market gardening where agro-climatic conditions are increasingly difficult (Rushigira, 2017).

Several researchers have paid particular attention to climate change and agriculture in general, and few studies have focused research specifically on climate change and market gardening. The present study aims to determine the impact of climate change on vegetable production in the extreme south of Mali through the perception and adaptation of market gardeners to climate change.

Thus, the main objective of this study is to understand the long-term perceptions and analysis the adaptation measures undertaken by market garden producers in the extreme south of Mali. More specifically, it aims to analysis the factors that influence farmers' perceptions and their adaptation to climate change and variability in the extreme south of Mali. Determine the factors 
that influence the choice of adaptation options for smallholder market gardeners in the communes of Sikasso, Bougouni and Koutiala.

\section{Materials and Methods}

\subsection{Choice of study areas}

Located in the extreme south of Mali, the Sikasso region is bordered to the north-west by the Koulikoro region, to the north-east by the Ségou region, to the east by Burkina Faso, to the south by Côte d'Ivoire and to the west by Guinea. The region of Sikasso is divided into seven circles which are: Bougouni, Kadiolo, Kolondiéba, Koutiala, Sikasso, Yanfolila andYorosso.

The relief is made up of hills and mountains in the south, and valleys and plains in the centre and north. The Kénédougou massif peaks at $800 \mathrm{~m}$. In addition, the Sikasso region is a reservoir of the Upper Niger watershed. It is crossed by numerous rivers, tributaries of the Niger River: the Sankarani in the north which collects water and discharges it into the Niger upstream of Bamako and the Bani in the south which joins the Niger at Mopti after collecting the waters of the Baoulé, Bagoé and Banifing.

The climate is of the tropical Sudanian type, subdivided into two climatic zones: the humid Sudanian zone and the Guinean zone. This region remains the most humid in Mali and the wettest (700 to $1,200 \mathrm{~mm} / \mathrm{year}$ ). The average annual temperature is $27^{\circ} \mathrm{C}$. It is also characterized by its predominance in agricultural production. The choice of this zone is based on the criteria of the climatic regime and its high vegetable production. Like the other regions of Mali, the circles surveyed are among the most vulnerable zones, like all the circles in the southern region, to the manifestations of climatic phenomena.

\subsection{Sampling}


The multi-stage random sampling technique was used for this study. First, three agricultural zones (Bougouni, Koutiala and Sikasso) in the far south were selected. In each agricultural zone, two communes were selected at random. In each of the communes, villages were sampled in proportion to the size of the village. Thus, five Communes were sampled in three Circles in the region. Two reasons prevailed in the choice of the communes and villages selected: the high concentration of market garden produce and the accessibility of the area.

Producers were selected from a list of households that are market gardening in the villages and this list was obtained from the World Vegetable Center (WCA) of the $<<$ Horticulture Scaling Project 2019>> program. A total of 224 producers were randomly selected. However, the study revealed only 194 valid responses and was used for data analysis. Table 1 shows the distribution of the sample in the surveyed areas.

\subsection{Collection method}

The data collection took place in 2 stages: the pre-collection or concept clarification phase and the actual collection. The questionnaire and the interview guide were used as a guide for the collection of information. The pre-collection phase: this is a transitional phase and allows for the detection of errors in the questionnaire. Then, the choice of producers was made randomly from an exhaustive list of all the beneficiaries of the World Vegetable Center (WCA) $<<$ Horticulture Scaling Project 2019>> project.

The focus group discussions were composed of resource persons and experienced producers with at least 15 years of experience in animal or crop production. On average, in each village 2 focus groups of 10 to 15 people (men and women) were set up separately in order to identify the perceptions and adaptation measures of each group. In addition, individual interviews 
were conducted with beneficiaries to understand the perceptions of other beneficiaries at the local level. A total of 194 market gardeners were surveyed. Questions focused on household and farm characteristics, infrastructure and institutional factors likely to influence the perceptions and use of adaptation methods by producers.

\subsection{Theoretical framework}

To analyse the determinants of the choice of adaptation measures to climate variability by smallholder market gardeners, the study used a multinomial logistic regression (NLM) model. This method has been used by several researchers such as (Kurukulasuriya and Mendelsohn, 2006) and (Hassan and Nhemachena, 2008), more recently by Magombo et al (2011) and Shongwe et al (2014) as methods of adaptation to the adverse effects of climate change. The advantage of the NLM is that when the characteristic is multiple, i.e. when it has several modalities, one can calculate the relative probabilities of encountering any one of these modalities if they are mutually exclusive.

In addition, Koch (2007) emphasises the usefulness of this model by describing the ease of interpretation of the estimates derived from it.

According to, Deressa et al. (2008) and Gbetibouo (2009) opined that the decision regarding whether or not to adopt any adaptation options is considered to be under the general framework of utility and profit maximization. Furthermore, it is assumed that a rational farmer uses adaptation methods only when the net benefit from using such a method is significantly greater than the cost of not doing so (Mendelsohn, 2012). Although the benefit is not directly observed, the action of economic agents is observed through the choices they make (Deressa et al., 
2008). Suppose that $Y_{j}$ and $Y_{k}$ represent a household's benefit for two choices, which are denoted by $U_{j}$ and $U_{k}$, respectively.

The linear regression model could then be specified as:

$$
U_{j}=\beta_{j}^{\prime} X_{i}+\varepsilon_{j} \text { and } U_{k}=\beta_{k}^{\prime} X_{i}+\varepsilon_{k}
$$

In the case of the adaptation method, if a household decides to use option $\mathrm{j}$, it follows that the perceived benefit from option $\mathrm{j}$ is greater than the benefit from other options

(i.e., k) which is depicted as

$$
U_{i j}\left(\beta_{j}^{\prime} X_{i}+\varepsilon_{j}\right)>U_{i k}\left(\beta_{k}^{\prime} X_{i}+\varepsilon_{k}\right), k \neq j
$$

Where $U_{i j}$ and $U_{i k}$ are the perceived benefits for adaptation options $\mathrm{j}$ and $\mathrm{k}$, respectively, by farmer $i, X_{i}$ is the vector of explanatory variables that influences the choice of the adaptation options, $\beta_{j}$ and $\beta_{k}$ are the parameters to be estimated, and $\varepsilon_{j}$ and $\varepsilon_{k}$ are the error terms assumed to be independently and identically distributed (Deressa et al., 2008).

The probability that a household will use method j from the set of climate change adaptation options could then be defined as follows:

$$
\begin{gathered}
P(Y=1 / X)=P\left(U_{i j}>U_{i k}(X)\right. \\
=P\left(\beta_{j}^{\prime} X_{i}+\varepsilon_{j}-\beta_{k}^{\prime} X_{i}-\varepsilon_{k}>0 / X\right) \\
\left.P\left(\beta_{j}^{\prime}-\beta_{k}^{\prime}\right) X_{i}+\varepsilon_{j}-\varepsilon_{k}>0 / X\right) \\
P\left(\beta^{*} X_{i}+\varepsilon^{*}>0 / X\right)=F\left(\beta^{*} X_{i}\right)
\end{gathered}
$$

Where $\mathrm{P}$ is the probability function, $U_{i j}, U_{i k}$ and $X_{i}$ are as defined above, is the random disturbance term, $\varepsilon^{*}=\varepsilon_{j}-\varepsilon_{k}$ is the vector of unknown parameters that can be interpreted as the 
net influence of the vector of explanatory variables that influences adaptation, and $F\left(\beta^{*} X_{i}\right)$ is the cumulative distribution function of $\varepsilon^{*}$ evaluated at $\beta^{*} X_{i}$. The exact distribution of $\mathrm{F}$ depends on the distribution of the random disturbance term, (Deressa et al., 2008; Gbetibouo, 2009).

For this study, the adaptation options or response probabilities are seven:

1. Increase irrigation

2. Drought-resistant crops

3. Use of different crop varieties

4. Agroforestry (Planting trees)

5. Soil conservation

6. Early and late planting

7. No adaptation

Another fundamental characteristic of the multinomial Logit is the property of independence from other events - of the ratio of the two probabilities associated with two possibilities $\mathrm{j}$ and $\mathrm{k}$ :

$$
\frac{P\left(Y_{i}=j\right)}{P\left(Y_{i}=k\right)}=\frac{\exp \left(x_{i} a_{i}\right)}{\exp \left(x_{i} a_{k}\right)}=\exp \left(x_{i}\left(a_{j}-a_{k}\right)\right.
$$

This report is independent of possibilities other than $\mathrm{j}$ and $\mathrm{k}$, this hypothesis is called the Independence of Irrelevant Alternatives (IIA). This property is verified ${ }^{1}$ if changing the set of choices (e.g. adding a possibility) does not change the odds ratios.

${ }^{1}$ See Thomas A. (2002), pages 101-103 
The estimation of the model parameters is carried out using log-likelihood function maximisation algorithms.

In Ethiopia, Deressa et al (2008), applied multinomial logistic regression (MNL) for the analysis of determinants of farmers' adaptation options and perceptions of climate change in the Nile Basin of Ethiopia. The results of their estimates indicate that the level of education, gender, age and income of the head of household, access to extension services and agricultural credit, climate information, agro-ecological zone and as well as temperature all influence farmers' choices.

In Mali, Sanogo et al (2017), collected data on 400 small farmers to elucidate farmers' perceptions of climate change in southern Mali and the potential consequences for delivery using the multinomial logit model. Their results revealed an increase in the frequency of high winds, dust, drought, high temperatures and the number of hot days as the main indicators related to climate change.

\subsection{Model specification}

\section{Functional form}

The analytical model used in this study is the multinomial logistic regression model that determines the method chosen by producers to adapt to climate change. It can be written as follows:

$$
\begin{aligned}
A_{i}= & \operatorname{Ln}\left(P_{J} / p_{i}\right) \beta_{0}+\beta_{1} * \operatorname{Exp}_{\text {Prod }_{i}}+\beta_{2} * \operatorname{Sex}_{\text {Prod }_{i}}+\beta_{3} * \operatorname{Memb}_{O P_{i}}+\beta_{4} * \text { Age }_{\text {Prod }_{i}}+ \\
& \beta_{5 *} \text { Tail }_{\text {men }}+\beta_{6} * \text { Acc }_{\text {crd }}+\beta_{7} * \text { Acc }_{\text {Vulg }}+\beta_{8 *} \text { Acc }_{\text {Infolimat }}+\beta_{9} \text { Mod_Ter }
\end{aligned}
$$

Where: Age_Prod: Age of producer; Tail_men: Household size; Acc_crd: Access to credit; Acc_Vulg: Access to extension service; Acc_Info_climate: Access to climate information; Mod_Ter: Mode of access to land. Table 2 provides more information on the nature of the 
variables.

Excel 2010 and STATA 14 software are used in data analysis.

\section{Results and discussion}

\subsection{Descriptive and econometric analysis of climate change adaptation measures}

\subsection{Adaptation measures perceived by producers}

Increasing cultivated land, soil and water conservation and the use of drought-resistant crops remain the main adaptation methods perceived by producers $(97.33 \% ; 93.05 \%$ and $84.49 \%$ respectively). These options could be a better option for coping with the adverse effects of climate change and variability. About $53 \%$ of producers said they rely only on their own weather forecasts to discern the right time for the first rainfall so that they sow early or wait for rain and then plant to avoid the associated effects of delayed rainfall. This is the information gathered during the group interviews. Furthermore $31.55 \%$ of the farmers felt that another option is to combine trees and crops (agroforestry) in the same plot for different purposes is also a good alternative to consider. In this way it is possible to reduce the risk of huge production losses due to extreme weather phenomena. In addition, $31.02 \%$ of the farmers surveyed stated that they perceived crop rotation as one of the adaptation measures. The adaptation measures least perceived by producers are mulching, working off-farm and use of wetlands and river valleys $(7.49 \%$ and $2.13 \%$ of producers respectively). The results are shown in Table 3 below.

\subsection{Farmers' adaptation to climate change and variability}

A descriptive analysis of the exogenous variables to be used in the output model was carried out in order to determine the variables that affect farmers' choice of adaptation measures to climate 
variability. Table 4 below summarises the explanatory variables assumed to affect farmers' adaptation strategies to the effects of climate variability experienced in the region over the past 20 years. The results of this analysis have been calculated on the basis of the response of certain market gardeners to the actual adaptation they have adopted.

The distribution of market gardeners by age shows that the age of market gardeners varies from 18 to 80 years, with an average age of 37.83 years. The size of households ranges from 3 to 120 people with an average of 35.71 people. The majority of respondents have access to climate information, extension and credit $(86.63 \%, 73.26 \%$ and $66.84 \%$ respectively). The vast majority of plots $(70.97 \%)$ of market gardeners are in VTICS (Garden Champ School) and BPHS. These are fields developed by the World Vegetable Center's $<<$ Horticulture Scaling Project $>>$ and which are accessible to market gardeners without compensation. The interpretation of variables such as farming experience, membership of a farmers' organization and the gender of the producer are omitted here to avoid redundancy.

\subsubsection{Constraints to adaptation}

During the individual interviews with producers, one question asked whether they have made any adjustments to mitigate the impacts of climate change and what the obstacles to this adjustment are. Lack of information, lack of money, lack of labor, high cost of labor, unavailability of credit, unavailability of inputs, high cost of inputs and low irrigation potential (Figure 1) were mentioned. Most of these constraints are associated with poverty: $85.56 \%$ of the study sample believe that the first obstacle to adapting to the effects of climate change is related to financial constraints (lack of financial resources). Lack of money prevents producers from obtaining the resources and technologies needed to facilitate adaptation to climate change. Yet research has shown that adjustment to climate change is cumbersome and costly. For example, if farmers do 
not have enough family labor or financial means to hire employees, they would find it very difficult to adapt. For example, low levels of irrigation are most certainly linked to the inability of producers to use irrigation water. In addition, $67.38 \%$ of producers do not have sufficient knowledge to manage the effects of climate change. In general, farmers in Mali are very poor and do not have the means to invest in irrigation and in research into technologies to adapt to climate change or to maintain their livelihoods in the face of extreme weather conditions, such as floods and drought.

\subsubsection{Results of the multinomial logit model and discussions}

Since the study focuses on the 6 major adaptation options (see methodology section), the regression results are also presented in the same specific order for each adaptation option, as shown in Table 5.

The results of the estimation of the adaptation measures of the multinomial logit model classified into 6 adaptation measures are presented in the table below.

The multinomial logit model is based on the hypothesis of independence of irrelevant alternatives (IIA). Thus, a validation test was carried out and we removed one by one the modalities and performed a Hausman test. The statistic of the $\chi 2(12)=0.000$ and with Prob $=1.000>0.05$ so one cannot reject $H 0$ Therefore, there is no significant difference when the modalities are removed one after the other. The specification of the multinomial logit is therefore appropriate for modelling climate change adaptation measures of market gardeners in the extreme south of Mali.

\section{Access to information on climate change}

Access to information on climate change has a positive and significant impact on the choice of producers to adapt to climate change by using irrigation, drought-resistant crops, different crop varieties, soil and water conservation and planting time (sooner or later). Relative to no adaptation 
options, having access to climate change information increases the likelihood of adaptation to climate change using irrigation, drought-resistant crops, different crop varieties, soil and water conservation and planting time (sooner or later).

\section{Mode of access to land}

Access to land positively and significantly influences the choice to adapt to climate change by using irrigation and different crop varieties. This means that land-owning producers are able to choose irrigation and use different crop varieties as a means of adapting to climate change than landless producers. Relative to no adaptation options, access to land increases the likelihood of practicing irrigation and using different crop varieties.

\section{Access to credit}

Access to credit positively and significantly influences the choice to adapt to climate change by using drought-resistant crops and soil and water conservation techniques. This means that producers with access to credit are more likely to choose drought-resistant crops and use soil and water conservation techniques as a means of adapting to climate change than producers without access to credit. In other words, having access to agricultural credit increases the likelihood of purchasing drought-resistant crops and practicing soil and water conservation techniques as adaptation measures.

\section{Access to the extension service}

The extension of extension services positively and significantly influences the choice to adapt to climate change by using different and timely (sooner or later) planting materials. This means that the more contact a producer has with extension services, the more useful information he or she receives on how to manage the effects of climate change compared to a farmer without 
access to extension services. Relative to no adaptation options, access to extension services increases the likelihood of practicing irrigation and using different crop varieties.

\section{Agricultural experience}

The agricultural experience has a positive and significant impact on the choice to adapt to climate change by combining trees and crops on the same plot. This means that more experienced producers are more likely to use agroforestry as an adaptation option compared to less experienced producers. In other words, the likelihood of practising agroforestry increases with agricultural experience.

\section{Gender of producer}

The gender variable has an inverse and significant influence on the choice not to adapt to climate change by using agroforestry. This means that female producers are less likely to adopt agroforestry as an adaptation option compared to male producers. The reason for this negative influence is that the practice of agroforestry requires more labor, equipment and access to information, yet women in general have limited access to information and lack equipment and agricultural labor in particular. This discourages women from taking up this activity.

\section{CONCLUSION}

This study has identified the socio-economic, infrastructural and institutional factors that influence producers' adaptation strategies to climate change in the extreme south of Mali. To this end, the multinomial logistic regression model was used, based on data collected from producers in the communes of Koumantou, Sanso and Zantiebougou in the Bougouni circle, Niéna in the Sikasso circle and Zankaso in the Koutiala circle to determine the factors that influence the choice of adaptation measures by producers to climate change. 
A review of the results indicates that the mode of access to land, access to climate change information, agricultural extension, agricultural experience and access to credit are the main endogenous strategies developed by producers to counteract the adverse effects of climate change.

In the light of the above, awareness-raising, information, exchange and sharing of experience relating to extreme climatic conditions could be undertaken to consolidate the different endogenous strategies developed by local producers in the implementation of policies to promote agriculture in general, and vegetable production in particular.

\section{Declaration of data availability}

The datasets used during the current article are available from the corresponding author on request.

\section{Declaration of interest statement}

The authors declare no potential conflict of interest.

\section{**3. Funding}

I have no funding to be able to pay the processing costs of my article that I want to publish in your International Journal of Economics and Statistics

\section{**4. Authors' contributions}

The first contribution is, the study that we propose is original insofar as there is no previous work borrowing such a procedure on this theme applied in Mali. 


\section{**5. Acknowledgments}

The author would like to thank Mamadou Abdoulaye Konté, Associate Professor of the Faculties of Economics at the University of Gaston Berger of Saint-Louis (Senegal) and Doctor Sokona Dagnoko, Country Director of SASAKAWA AFRICA ASSOCIATION, for their valuable contribution to the creation of this paper

\section{Authors' information (optional)}

'Not applicable' for that section.

\section{References}

\section{References}

Banque Mondiale (2014). L'agriculture au service du développement in rapport sur le développement dans le monde, Editions De Boeck, Distribution Nouveaux horizons ARS, Paris.

Bates, B.C, Z.W. Kundzewicz, S.Wu, and J.P. Palutikof, 2008. Climate change 2007: synthesis report: an assessment of the Intergovernmental Panel on climate change. Intergovernmental "Panel on climate change, Geneva, Switzerland.

Bhavnani, R., S. Vordzorgbe, M. Owor, and F. Bousquet. 2008. Status of disaster risk reduction in the sub-Saharan Africa region. The World Bank, Washington, DC.

CEDEAO-CSA/OCDE. 2008. Le climat et les changements climatiques. Atlas de l'Intégration Régionale en AFrique de l'Ouest. 13 p.

Htpp://www.atlas-ouestafrique.org 
Deressa et al. 2008. "Analyzing the Determinants of Farmers " Choice of Adaptation Methods and Perceptions of Climate Change in the Nile Basin of Ethiopia." Washington, D.C.USA.

GIEC (2013). Climate Change 2013: The Physical Science Basis. Contribution of Working Group I to the Fifth Assessment Report of the Intergovernmental Panel on Climate Change. Stocker T.F., Qin D., Plattner G.-K., Tignor M., Allen S.K., Boschung J., Nauels A., Xia Y., Bex V., Midgley P.M. (eds.), Cambridge University Press, Cambridge, United Kingdom and New York, NY, USA, 1535 pp.

Hartman, D.L, A.M.G. Klein Tank? M. Rusticucci, L.V Alexander, S. Bronniman, Y.Charabi rt al. 2013. Observations atmosphere and surface. Pp 159-254 in T.F. Stocker, D.Qin, G.- k. Plattner ? M.Tignor, S.K. Allen, J. Bosching et al. , eds. Climate change 2013: The physical science basis. Contribution of working Group I to the fifth assessment.

Hassan, R., \& Nhemachena, C. (2008). Determinants of African farmers's strategies for adapting to climate change: Multinomial choice analysis. African Journal of Agricultural and Resource Economics, 2(1), 83104.

Kurukulasuriya, P., and R. Mendelsohn. 2006. Crop selection: Adapting to climate change in Africa. CEEPA Discussion Paper No. 26. Centre for Environmental Economics and Policy in Africa. Pretoria, South Africa: University of Pretoria.

Magombo et al. 2011. "Incidence of Indigenous and Innovative Climate Change Adaptation Practices for Smallholder Farmers "Livelihood Security in Chikhwawa District, Southern Malawi." African Technology Policy Studies Network (ATPSN). Research Paper No.14. Lilongwe, Malawi.

Mendelsohn, R. (2012). The economics of adaptation to climate change in developing countries. Climate Change Economics, 3(2), 1250006. 
Ministère de l'Environnement et de Développement Durable (MEDD), 2018. Plan d'investissement pour une économie verte et résilience aux changements climatiques pour le Mali. Rapport Final. $N^{\circ} 2461 / M E D D / A E D D-D M R F, 172 p$.

PNUD, 2014. Renforcer les capacités d'adaptation et la résilience aux changements climatiques dans le secteur de l'agriculture au mali. http://www.undp-alm.org/projects/ldcf-mali www.undpalm.org/projects/ccaf

RUSHIGIRA C, (2017). Analyse technico-économique de la production maraîchère à Kamanyola dans la plaine de la Rizizi/RDC : Contraintes et stratégies d'acteurs. Mémoire de Master en développement, Environnement Sociétés, Université de Liège ; 129p.

Sanogo K, Binam J, Bayala J, Villamor G.B, Kalinganire A et Dodiomon S, 2017. Farmers' perceptions of climate change impacts on ecosystem services delivery of parklands in southern Mali. DOI 10.1007/s10457-016-9933-z.

Seguin, B. «Le changement climatique : conséquences pour les végétaux », Quaderni [En ligne], $71 \mid$ Hiver 2009-2010, mis en ligne le 05 janvier 2012, consulté le 14 avril 2020. URL: http://journals.openedition.org/quaderni/525 ; DOI : 10.4000/quaderni.525

Shongwe P. and all (2014). Adaptation Strategies by Households: A cas of Mpolonjeni area Development Programme (ADP in Swaziland.doi:10.5296/jas.v2i1.4890 URL: http://dx.doi.org/10.5296/jas.v2i1.4890.

THOMAS A., Économétrie des variables qualitatives, Dunod, 2000. 103p 
Figure 1: Constraints related to adaptation

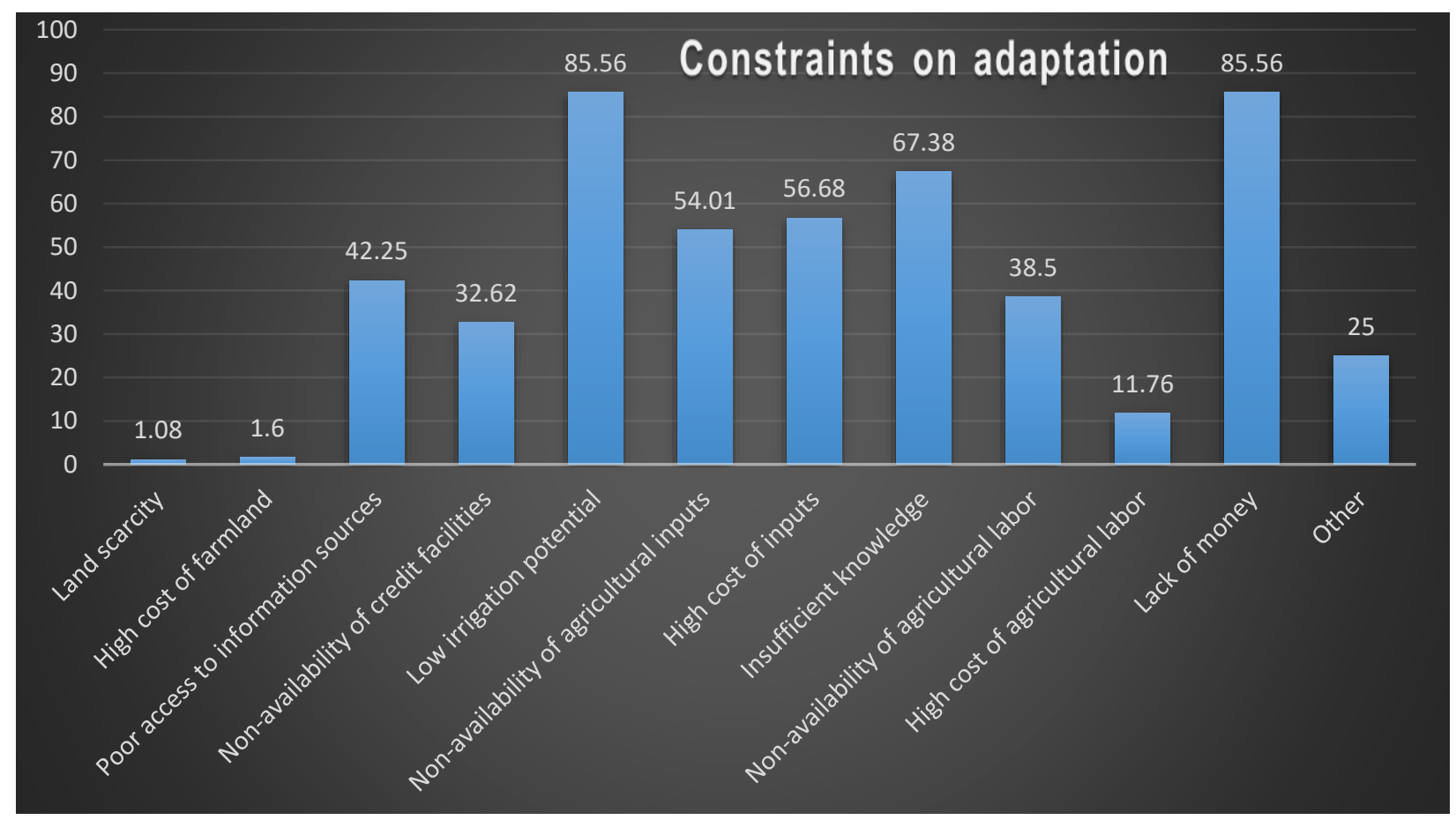

Source: Author's calculation based on Field survey, August-October 2019 
Table 1. Composition of the study sample

\begin{tabular}{|c|c|c|c|c|c|}
\hline \hline \multirow{2}{*}{$\begin{array}{c}\text { Agricultural } \\
\text { area }\end{array}$} & Commune & Town & $\begin{array}{c}\text { Number of } \\
\text { housework }\end{array}$ & $\begin{array}{c}\text { Size } \\
\text { sample }\end{array}$ & $\begin{array}{c}\text { Response } \\
\text { rate (\%) }\end{array}$ \\
\hline \multirow{3}{*}{ Bougouni } & Koumantou & Choubougou & 24 & 24 & 100 \\
\cline { 2 - 6 } & Sanso & Ména & 24 & 24 & 100 \\
\cline { 2 - 6 } & Zantiébougou & Koury & 24 & 24 & 100 \\
\hline \multirow{2}{*}{ Koutiala } & Zankaso & Sokourani & 80 & 50 & 62 \\
\hline \multirow{2}{*}{ Sikasso } & Niéna & N'golotiorla & 24 & 24 & 100 \\
\cline { 2 - 6 } & & Tiécourala & 24 & 24 & 100 \\
\hline \multicolumn{2}{|c|}{ Total } & & 24 & 194 & 86,6 \\
\hline
\end{tabular}

Source: Field survey, August-October 2019 
Table 2. List of independent variables and expected signs

\begin{tabular}{|l|c|c|c|}
\hline \multicolumn{1}{|c|}{ Explanatory variables } & Coding & Category & $\begin{array}{c}\text { Expected } \\
\text { sign }\end{array}$ \\
& & & \\
\hline Age of the producer & Year & Continuous & $+/-$ \\
\hline Size of household & Year & Continuous & $+/-$ \\
\hline Experience & Year & Continuous & + \\
\hline Gender of producer & $1=$ Male, $0=$ Female & Qualitative & $+/$ - \\
\hline OP membership & $1=$ Yes, $0=$ No & Qualitative & + \\
\hline Access to credit & $1=$ Yes, $0=$ No & Qualitative & + \\
\hline Access to extension & $1=$ Yes, $0=$ No & Qualitative & + \\
\hline Mode of access to land & $1=$ Yes, $0=$ No & Qualitative & + \\
\hline $\begin{array}{l}\text { Access to climate } \\
\text { information }\end{array}$ & $1=$ Yes, $0=$ No & Qualitative & + \\
\hline Source: Auth & & & + \\
\hline
\end{tabular}

Source: Author according to the theoretical and empirical literature review 
Table 3: Adaptation option adopted by producers

\begin{tabular}{lcc}
\hline Perceived adaptation option by producer & Number of producer & $\begin{array}{c}\text { \% per } \\
\text { producer }\end{array}$ \\
\hline Off-farm employment & 4 & 2.13 \\
Increase irrigation & 9 & 4.81 \\
Mulching & 14 & 7.49 \\
Use of wetlands/river valleys & 4 & 2.13 \\
Drought-resistant crop & 158 & 84.49 \\
Different crop varieties & 29 & 15.51 \\
Use of a traditional crop variety & 29 & 15.51 \\
Increase in cultivated land & 182 & 97.33 \\
Crop rotation & 59 & 31.02 \\
Intercropping & 26 & 13.90 \\
Agroforestry use (Tree planting) & 58 & 31.55 \\
Water and soil conservation & 174 & 93.05 \\
Early and late planting & 98 & 52.41 \\
\hline Number of observations & 54 &
\end{tabular}

Number of observations $=194$ 
Table 4: Statistical description of variables in the multinomial logistic regression model

Qualitative variables Absolute frequency Relative frequency (\%)

Gender of producer

Woman

128

66

Man

66

34

Access to climate info

168

86,63

OP membership

111

57

Access to agricultural credit

6433

Access to extension

142

73,26

Mode of access to land

Heritage

$-$

Purchase

45

23.12

Metayage

4

2.15

Donation

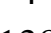

2.15

138

70.97

Rental

3

1.61

\begin{tabular}{lcc}
\hline Qualitative variables & Averages & Standard Deviations \\
\hline Age of the producer & 37.83 & 11.26 \\
Household size & 10 & 5.11 \\
Experience & 12.66 & 7.97 \\
\hline
\end{tabular}

Source: Author's calculation based on Field survey, August-October 2019 
Table 5: Results of the Multinomial Logit Model of Climate Change Adaptation Strategies

\begin{tabular}{|c|c|c|c|c|c|c|c|c|c|}
\hline \multirow{2}{*}{ Explanatory variables } & \multicolumn{3}{|c|}{ Increase irrigation } & \multicolumn{3}{|c|}{ Drought-resistant crops } & \multicolumn{3}{|c|}{ Different varieties of crops } \\
\hline & Coef. & $\operatorname{Exp}(\boldsymbol{\beta})$ & \begin{tabular}{|l|} 
P- \\
values
\end{tabular} & Coef. & $\operatorname{Exp}(\boldsymbol{\beta})$ & P-values & Coef. & $\operatorname{Exp}(\boldsymbol{\beta})$ & $\begin{array}{c}\text { P- } \\
\text { values }\end{array}$ \\
\hline Constant $\left(\beta_{0}\right)$ & $-2.436 * *$ & .087 & 0.043 & $--3.085 * * *$ & .046 & 0.009 & -1.125 & .325 & 0.283 \\
\hline Size of household & 0.010 & 1.010 & 0.288 & 0.014 & 1.014 & 0.170 & -0.010 & .990 & 0.280 \\
\hline Experience & 0.036 & 1.036 & 0.812 & 0.030 & 1.030 & 0.459 & 0.026 & 1.026 & 0.359 \\
\hline Gender of producer $(1 / 0)$ & -0.090 & .914 & 0.779 & -0.027 & .973 & 0.953 & 0.640 & 1.896 & 0.106 \\
\hline OP membership (1/0) & -0.102 & .903 & 0.954 & -0.561 & .571 & 0.143 & 0.003 & 1.003 & 0.993 \\
\hline Access to credit (1/0) & 0.022 & 1.022 & 0.114 & $0.734^{*}$ & 2.083 & 0.060 & 0.227 & 1.255 & 0.542 \\
\hline
\end{tabular}

Reference category: No adaptation

$* \mathrm{p}<0.10, * * \mathrm{p}<0.05, * * * \mathrm{p}<0.01$

\begin{tabular}{|l|l|l|l|}
\hline & Agroforestry & Soil and water conservation & Early and late planting \\
\hline
\end{tabular}




\begin{tabular}{|c|c|c|c|c|c|c|c|c|c|}
\hline & Coef. & $\operatorname{Exp}(\boldsymbol{\beta})$ & P-values & Coef. & $\operatorname{Exp}(\boldsymbol{\beta})$ & $\begin{array}{c}\mathrm{P}- \\
\text { values }\end{array}$ & Coef. & $\operatorname{Exp}(\boldsymbol{\beta})$ & $\begin{array}{c}\mathrm{P}- \\
\text { values }\end{array}$ \\
\hline Constant $\left(\beta_{0}\right)$ & $-.2869 * * *$ & .044 & 0.006 & $-2.680 * *$ & .069 & 0.028 & $-2.647^{* *}$ & .071 & 0.031 \\
\hline Age of the producer & -0.004 & .996 & 0.887 & $0.069 * *$ & 1.072 & 0.015 & 0.029 & 1.029 & 0.295 \\
\hline Size of household & 0.002 & 1.002 & 0.846 & -0.014 & .986 & 0.152 & 0.006 & 1.006 & 0.593 \\
\hline Experience & $0.069 * *$ & 1.072 & 0.032 & -0.054 & .947 & 0.114 & 0.004 & 1.004 & 0.908 \\
\hline Gender of producer $(1 / 0)$ & $-1.389 * * *$ & 4.009 & 0.000 & -0.270 & .763 & 0.584 & -0.225 & .798 & 0.624 \\
\hline OP membership (1/0) & 0.430 & 1.538 & 0.244 & 0.070 & 1.072 & 0.868 & -0.060 & .942 & 0.879 \\
\hline Access to credit (1/0) & -0.018 & .982 & 0.963 & $0.968 * *$ & 2.633 & 0.022 & 0.227 & 1.255 & 0.580 \\
\hline Access to extension $(1 / 0)$ & 0.524 & 1.689 & 0.195 & 0.397 & 1.488 & 0.378 & $0.729 *$ & 2.074 & 0.093 \\
\hline Mode of access to land & -0.105 & .900 & 0.471 & 0.084 & 1.087 & 0.659 & 0.162 & 1.176 & 0.329 \\
\hline Access to climate info $(1 / 0)$ & 1.038 & 2.823 & 0.104 & $1.885^{* * *}$ & 6.584 & 0.001 & $1.731 * * *$ & 5.648 & 0.001 \\
\hline
\end{tabular}

Reference category: No adaptation

$* \mathrm{p}<0.10, * * \mathrm{p}<0.05, * * * \mathrm{p}<0.01$ 


\section{Annex}

Figure 2: Mapping the southern region of Mali

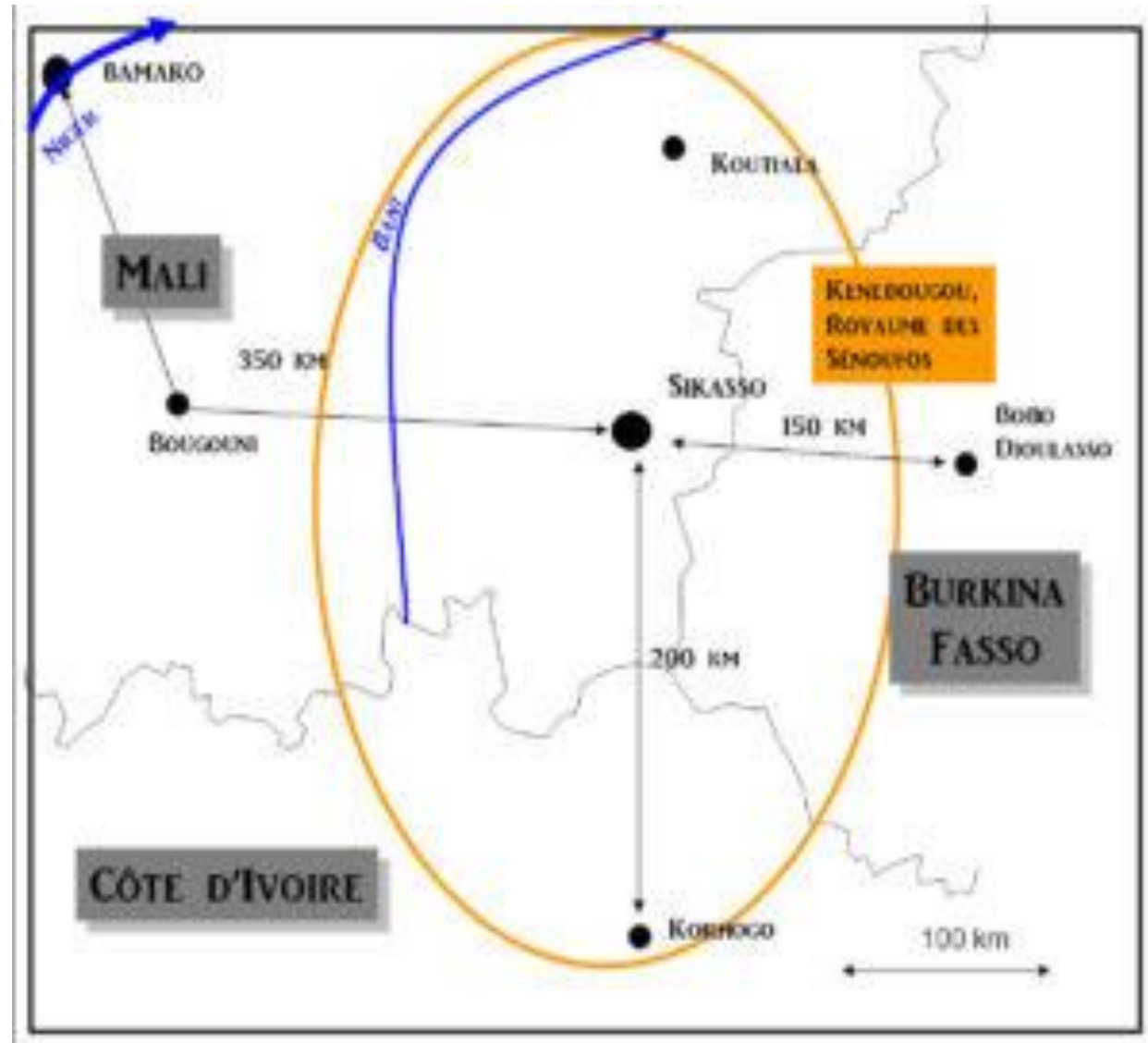





\section{Figures}

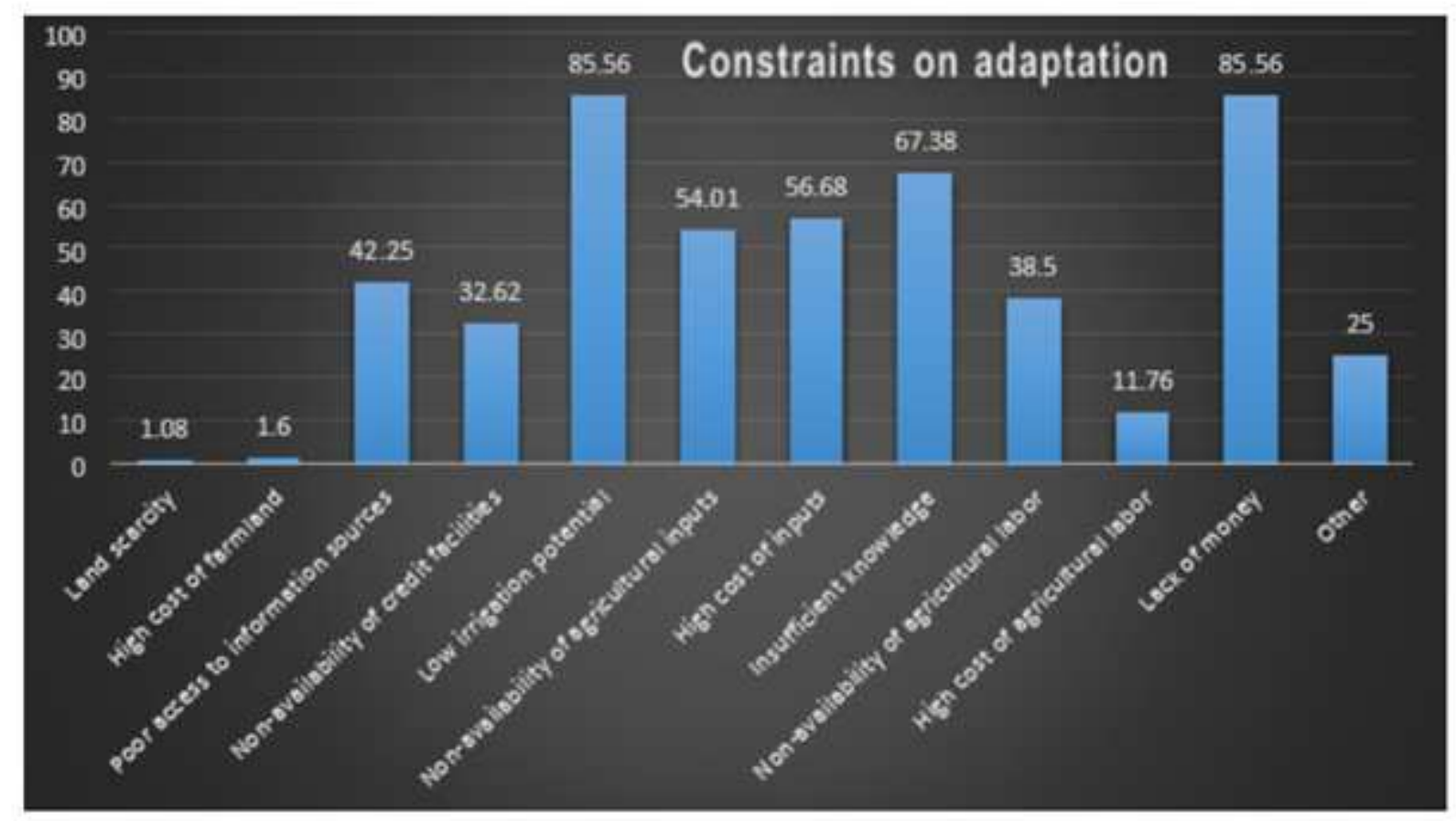

Figure 1

Constraints related to adaptation. Source: Author's calculation based on Field survey, August-October 2019 


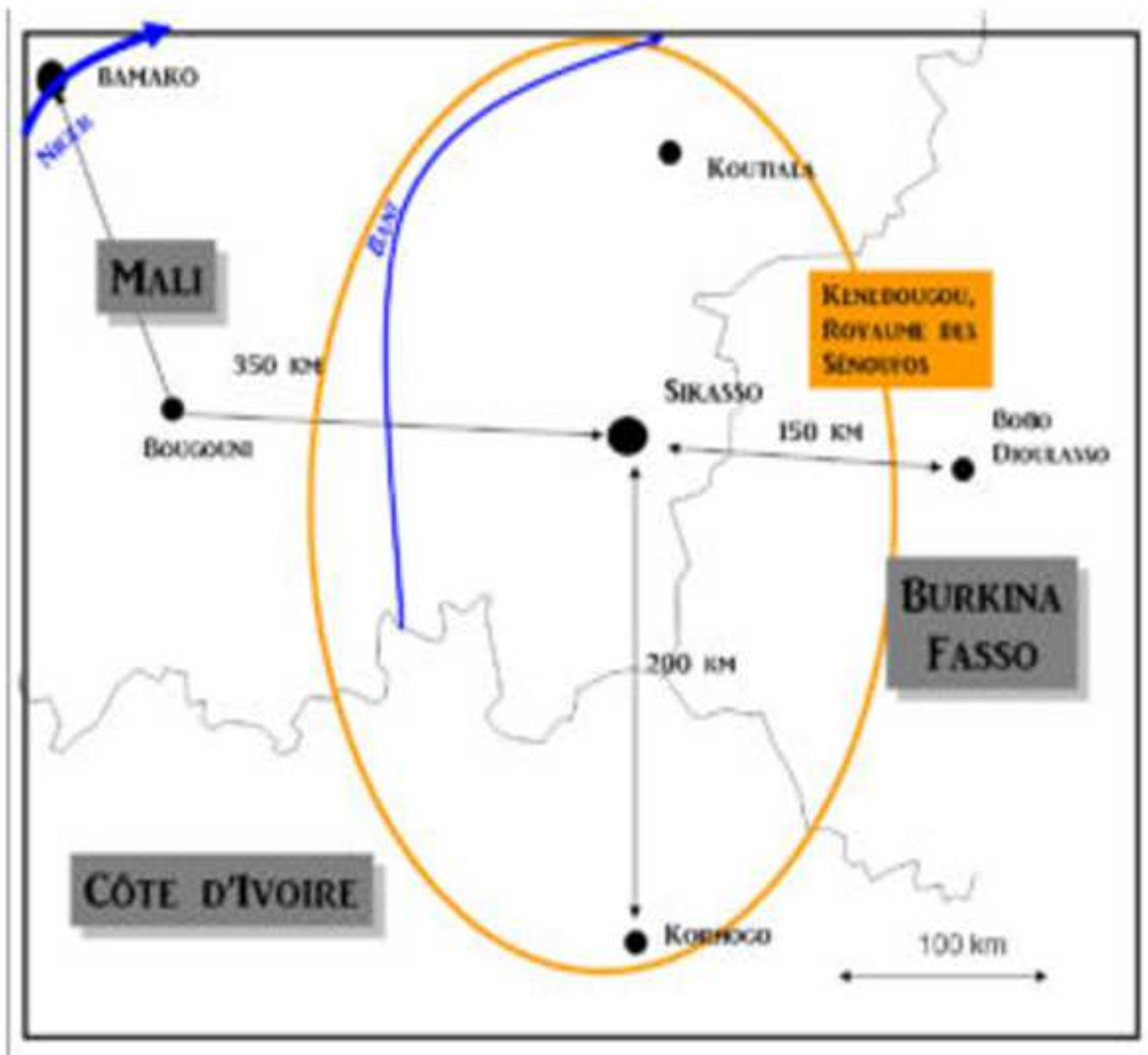

Figure 2

Mapping the southern region of Mali 